\title{
Adult recaptures of farmed Atlantic salmon post-smolts allowed to escape during summer
}

\author{
Ove T. Skilbrei* \\ Institute of Marine Research, PO Box 1870 Nordnes, 5817 Bergen, Norway
}

\begin{abstract}
The influence of time of escape on survival to adulthood was tested in farmed Atlantic salmon Salmo salar smolt and post-smolts. Escape events were simulated in a small fjord in western Norway during and after the natural period of smolt migration by releasing 6 groups of individually tagged smolts and post-smolts ( 2000 fish in each group) every second week from 27 May to 5 August 2005 . With the exception of a lower return rate of the first released group $(0.31 \%)$, the recapture rates were very similar $(0.85$ to $1.05 \%$ ) and did not vary significantly with time of release. Of the 100 recaptures, $57 \%$ were 1 -sea-winter (1SW) salmon, $25 \%$ were $2 \mathrm{SW}$ and $18 \%$ returned as $3 \mathrm{SW}$ salmon. Release date did not influence the sea age but affected the weights of the recaptured adults moderately. Fifty-four percent of the fish were recaptured in the vicinity of the release site, most of them in the freshwater effluent from a hydropower plant. The rest were spread along the coast of Norway and in rivers ( $26 \%$ of the distant recaptures) over distances of 100 s of kilometres. The present study shows that farmed salmon escaped during their first summer in sea cages - after the natural time for smolt migration in spring - are still capable of adopting the marine migratory pattern of their wild conspecifics. This suggests that escapes at this time of the year are a hazard to the conservation of wild salmon populations.
\end{abstract}

KEY WORDS: Escaped farmed salmon $\cdot$ Post-smolt $\cdot$ Migration $\cdot$ Timing $\cdot$ Recapture $\cdot$ Sea age

\section{INTRODUCTION}

Atlantic salmon farming has grown rapidly since the mid-1960s, and has been linked to declines in natural populations (Ford \& Myers 2008). The incidence of escaped farmed salmon tends to be higher in the vicinity of concentrations of fish farms (Fiske et al. 2006). If the escapees manage to interbreed (Lura \& Sægrov 1991, Naylor et al. 2005, Jonsson \& Jonsson 2006), they may interfere with the genetic structure of wild stocks because of genetic differences between wild and domesticated strains (McGinnity et al. 2003, Skaala et al. 2005, 2006, Hindar et al. 2006, Ferguson et al. 2007). Farmed salmon that escape from cages have thus become a problem both for the fish-farming industry itself and for the conservation of wild stocks.

Most Atlantic salmon populations have a welldefined migratory cycle: the majority of the young salmon leave the river as smolts in spring when they are 1 to 5 yr old and migrate to their feeding grounds in the open sea, where they remain for 1 yr (1-sea-winter fish, 1SW) or longer (2 to $3 \mathrm{SW}$ ) before returning to their home river to spawn (Youngson \& Hay 1996). Just prior to the smolt run, the fish develop the ability to osmoregulate in seawater during the smoltification process (Hoar 1976). Post-smolt is the life stage from the time the smolt departs from the river until the end of its first winter at sea.

Studies of spawning behaviour have shown that it is very likely that a fish escaping as a young salmon, at the smolt stage, will display spawning behaviour when maturing that is more similar to that of wild salmon than to farmed salmon that have escaped from net pens just before their entry into rivers (Fleming et al. 1996, 1997). Their outward appearance will also be comparable to wild salmon, due to less pronounced fin 
erosions and other environmentally induced external signs typical of cultured fish in cages (Fiske et al. 2005). Scale readings of fish caught in rivers led the Directorate of Fisheries to assume that a large proportion of escaped farmed salmon in Norwegian rivers had escaped at smolt stage (Sægrov \& Urdal 2006). In order to minimize the risk of smolt escapes, a number of national regulations regarding aquaculture operational procedures came into force in 2008, among them the obligation to implement a risk analysis for handling and transporting of smolts and to ensure that the mesh size used in net pens is correctly adapted to the size of the fish (e.g. Regulation 2008-06-17 No. 822).

There is no evidence to indicate that escaped smolts survive and grow to adult size if they do not follow the migration pattern of wild salmon into the open sea. The onset of migratory behaviour in wild fish is typically timed with the season and/or some physiological factor that triggers migration to feeding or spawning grounds (Smith 1985). Wild smolts in western Europe usually leave rivers in spring and early summer (Hvidsten et al. 1998, Byrne et al. 2003). The recapture rates of adults released as smolts and post-smolts have been in accordance with the timing of the migration of wild smolts to the open sea. Hansen \& Jonsson (1989) released the offspring of wild parents on various dates and found that the tag recapture rate peaked for smolts released in spring. They observed that survival rates in the sea were low for hatchery-reared fish released before or after the natural period of migration of the wild smolts and suggested that the window for smolt migration was open for only a short period in spring and closed gradually in the course of the summer.

The following 2 questions are important for assessing the risks of escapes of farmed salmon. (1) At what time during the season do cultured post-smolts begin to migrate if they escape, and (2) do they survive to adulthood? The first issue has been previously studied by surveying the migratory behaviour of smolts and postsmolts released on various dates from May to October in a small Norwegian fjord (Skilbrei 2010). The fish released in May and in late June migrated rapidly out of the fjord during the first few days, with a behavioural pattern similar to the migratory performance of smolts released in other areas (Thorstad et al. 2004, LaCroix 2008). The rate of movement out of the fjord slowed down in mid-August and dropped radically in September and October, when the dispersal out of the fjord took many weeks or even months. It was therefore suggested that migratory performance is not limited to the smolt stage, but that farmed post-smolts may also be able to display marine migratory behaviour if they escape during their first summer in sea cages (Skilbrei 2010). However, this previous study did not shed light on the next important issue concerning survival in sea.
The present study was designed as a detailed study of the effect of time of escape-during the first summer in sea cages - on survival and potential migratory behaviour. On the basis of current knowledge of natural migratory behaviour obtained from release experiments with the offspring of wild salmon (Hansen \& Jonsson 1989), it was assumed that recaptures, reflecting migratory performance, of adults experimentally released as post-smolts would decline with progressing release time during their first summer in sea cages. Knowledge of the relationship between escape time and the development of migratory behaviour could be useful for management if efforts are to be made to reduce the negative interactions with wild fish, but such data on timing have not hitherto been reported for a farmed strain that has been held in culture for many generations. The present study reports adult recaptures of individually tagged smolts and postsmolts of a farmed strain that were tagged and released from a fish farm every second week from May to August 2005 in a small fjord in western Norway.

\section{MATERIALS AND METHODS}

Fish tagging and releases. The fish were of the domesticated Aqua Gen strain that is widely used in fish farming in Norway and were produced at the hatchery at Matre Research Station (Institute of Marine Research). One-year-old smolts were reared in outdoor $5 \mathrm{~m}$ diameter tanks. Six release groups of $\sim 2000$ fish each were tagged with T-bar anchor tags (Hallprint). They were released every other week from 27 May to 5 August 2005 (Table 1) from sea-cages at a fish farm $1 \mathrm{~km}$ from Matre Research Station, at the head of the $21 \mathrm{~km}$ long Masfjord in western Norway. A salinity gradient established at the site due to the freshwater effluent from a nearby hydropower plant. The mean daily salinities were $14.4 \pm 3.4( \pm \mathrm{SD}), 23.3 \pm$ 4.0 and $28.4 \pm 1.5$ at depths of 1,3 and $5 \mathrm{~m}$, respectively, from 19 May to 5 August. The locality has been described in more detail by Skilbrei (2010), who studied the migratory behaviour of smolts and post-smolts that were released from the same fish farm in 2008.

The 2 first release groups were tagged with T-bar anchor tags on 3 and 4 May in freshwater. Fish were anaesthetized with MS-222 and length and weight measured (weights measured only of an exemplary sub-sample of fish). Physiological measurements to evaluate smolt quality were not made, but it was assumed that smolt development was advanced as the fish were silvery and had to be treated carefully during tagging due to loose scales. Mean $( \pm \mathrm{SD})$ length and weight of the fish were $17.0 \pm 1.2 \mathrm{~cm}$ and $54.6 \pm 13.4 \mathrm{~g}$, respectively. 
Table 1. Salmo salar. Number of fish released on 6 dates during spring and summer 2005 and number of recaptured salmon with sea age $\geq 1+$ yr reported from Masfjord, SW Norway and more distant recapture sites (see Fig. 2) (no. of fish recaptured in rivers in parentheses)

\begin{tabular}{|lccccccc|}
\hline & \multicolumn{1}{c}{ Release date } & \multicolumn{2}{c}{ Total } \\
\cline { 2 - 6 } & 27 May & 10 Jun & 24 Jun & 8 Jul & 22 Jul & 5 Aug \\
\hline Released salmon & 1936 & 2002 & 1978 & 2000 & 2000 & 1999 \\
Recaptures in Masfjord & 1 & 7 & $10(2)$ & $11(2)$ & 17 & $8(1)$ & 11915 \\
Distant recaptures & $5(1)$ & $12(3)$ & $9(3)$ & $7(2)$ & $4(1)$ & $9(2)$ & $46(12)$ \\
Total recaptures & 6 & 19 & 19 & 18 & 21 & 17 & 100 \\
\hline
\end{tabular}

Tagged and untagged fish were exposed to higher salinities on 19 and 20 May, when they were dip-netted over to transport tanks, transported to $5.5 \times 5.5 \mathrm{~m}$, $7 \mathrm{~m}$ deep cages and towed to the sea-cage facility in separate transports. Mortality was observed in Release group 1 ( $\mathrm{n}=50$ fish) during the first days in cages. Mortality was negligible in Release group 2 ( $\mathrm{n}=2$ ). A veterinarian checked dead fish on 23 May, but found no evidence of disease and concluded that the mortality was probably due to handling and/or stress during transport. The appetite and general behaviour of the fish appeared to be normal at that date.

The fish of Releases 3 and 4 were randomly selected from the 2 cages that housed the untagged fish. They were tagged and moved to 2 new cages at the fish farm on 13 to 17 June. The mean $( \pm \mathrm{SD})$ length and weight of the fish were $18.2 \pm 1.4 \mathrm{~cm}$ and $67.1 \pm 15.7 \mathrm{~g}$, respectively. The last 2 release groups were tagged on 14 and 15 July when the fish averaged $20.5 \pm 1.4 \mathrm{~cm}$ in length, and weighed $92.5 \pm 19.0 \mathrm{~g}$.

The letters HI (Norwegian acronym for the Institute of Marine Research), the IMR internet address (imr.no) and postal code were printed on the T-bar tags in addition to an individual alphanumeric code. The monetary reward was 100 NOK per T-bar anchor tag returned. Information about the reward was available on the IMR Internet home page.

Statistical analysis. The LOGISTIC Procedure of SAS Software Package version 9.1 (SAS Institute) was used to fit a Generalized Linear Model (GLM) (McCullagh \& Nelder 1989), with a logistic link function to test for differences in (1) the probability of fish being recaptured (binomial response variable) with release date and sea age, and (2) the probability of fish being recaptured with release date and locality of recapture;

$$
\begin{gathered}
\log [p /(1-p)]=I+A_{\text {date }}+B_{\mathrm{SW}}+A_{\text {date }} \times B_{\mathrm{SW}} \\
\log [p /(1-p)]=I+A_{\text {date }}+C_{\text {local } / \text { dist }}+A_{\text {date }} \times C_{\text {local } / \text { dist }}
\end{gathered}
$$

where $p$ is the probability of recapture, $I$ is the intercept and the categorical parameters $A_{\text {date }}$ and $B_{\mathrm{SW}}$ are the parameter estimates for the effects of release date and sea age (i.e. sea winter), respectively, and $C_{\text {local/dist }}$ is distance to recapture site (2 categories; fish recaptured in Masfjord or elsewhere). Interaction terms are included.

The GLM module of the statistical package STATISTICA (StatSoft) was utilized for the analysis of the weights of the recaptured salmon $(w)$ with release date and sea age as category variables and smolt length as a covariate:

$$
W=I+A_{\text {date }}+B_{\mathrm{SW}}+S S+A_{\text {date }} \times B_{\mathrm{SW}}
$$

where $S S$ is standardized smolt length. $S S$ gives the relative size of the individual compared to the other members of the group and was calculated from the formula:

$$
S S=(L-\bar{L}) / \mathrm{SD},
$$

where $L$ is the length of the individual, $\bar{L}$ is mean length in a specific release group and SD is standard deviation within the group.

\section{RESULTS}

Recapture rates and the sea age of the 6 groups released on various dates during the summer were very similar to each other, except for a lower recapture rate of the fish released in May (Fig. 1). The probability of being recaptured was independent of the release date (Binomial Response Model, Eq. 1: Wald statistics, $W=5.3, \mathrm{df}=5, p_{\text {date }}=0.38$ ), but the recaptures of the first release deviated significantly from the model $\left(W_{\text {May }}=5.1\right.$, df $\left.=1, p_{\text {May }}<0.05\right)$. More fish returned as $1 \mathrm{SW}$ fish and sea age had a significant effect on the probability of recapture $\left(W_{\mathrm{SW}}=18.6, \mathrm{df}=2, p_{\mathrm{SW}}<\right.$ 0.0001 ; Fig. 1). The insignificant interaction term between release date and sea age $\left(W_{\text {date }} \times \mathrm{sw}=5.0, \mathrm{df}=\right.$ $3, p_{\text {date }} \times \mathrm{Sw}=0.89$ ) implies that sea age did not vary with time of release.

Sea age clearly affected the weights of the fish recaptured (Eq. 3: $\mathrm{R}^{2}=0.87, F=26.9, F_{\mathrm{SW}}=188$, with $\left.\mathrm{df}=2, p_{\mathrm{SW}}<0.0001\right)$. Smolt size did not $\left(F_{\mathrm{SS}}=0.1, \mathrm{df}=1\right.$, $\left.p_{S S}=0.74\right)$, but release date $\left(F_{\text {date }}=3.1\right.$, df $=5, p_{\text {date }}<$ $0.05)$ and its interaction with sea age $\left(F_{\text {date } \times \text { Sw }}=2.0\right.$, 


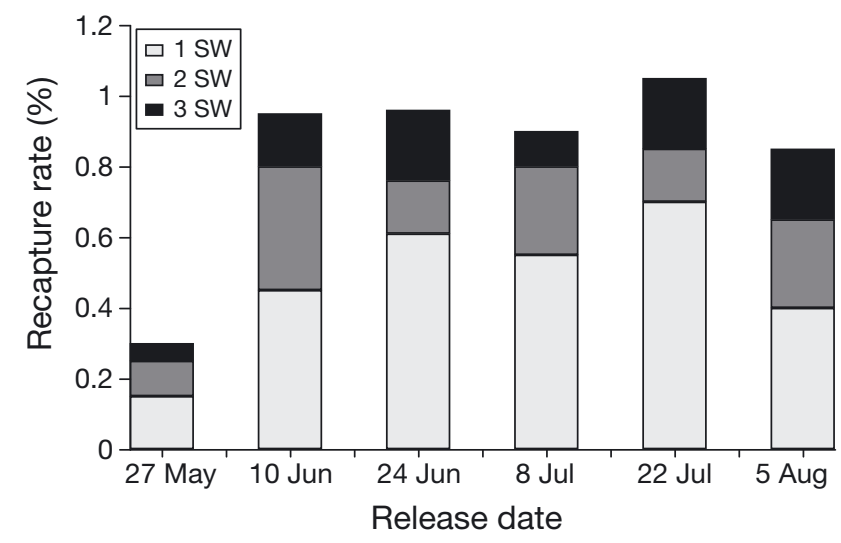

Fig. 1. Salmo salar. Recapture rates (\% of released numbers) of 1-sea-winter (1SW), 2SW and 3SW salmon released as smolts and post-smolts on 6 dates during spring and summer 2005

$\left.\mathrm{df}=10, p_{\text {date }} \times \mathrm{sw}<0.05\right)$ significantly influenced the weights of the recaptured fish. The main reason for these significant effects was slightly lower growth in the sea of the smolts released at the 2 last release dates. The differences in weight were not significant within the 3 sea age classes. The mean $( \pm \mathrm{SD})$ size of the 1SW salmon that were released as smolts in late July and early August was $1.50 \pm 0.36 \mathrm{~kg}$, and the mean size of those released earlier (27 May, 10 June, 24 June, and 8 July) was $1.61 \pm 0.57 \mathrm{~kg}$ (Student $t$-test, $\mathrm{p}=0.46$ ). The corresponding weights (means $\pm \mathrm{SD}$ ) of the $2 \mathrm{SW}$ and $3 \mathrm{SW}$ salmon were $4.21 \pm 1.19$ versus $4.76 \pm 0.80 \mathrm{~kg}(\mathrm{p}=0.21)$ for the late releases, and $7.07 \pm 0.98$ versus $9.44 \pm 2.85 \mathrm{~kg}(\mathrm{p}=0.053)$ for earlier releases, respectively.

Of all fish recaptured, 54\% were from Masfjord (Table 1). The majority were recaptured within $1 \mathrm{~km}$ of the release site (51 of 54 fish). Most of them were angled where the freshwater effluent from the hydropower plant drains to the inner bay of the fjord (42 fish) (this is a popular site for angling salmon and requires a fishing license). Four entered the Matre River at the head of the Masfjord, $0.8 \mathrm{~km}$ from the release site, and 1 was captured in a small river $4 \mathrm{~km}$ away.

The fish that were recaptured outside Masfjord were dispersed over a large area, from the north to the south of Norway (Fig. 2), and $26 \%$ were reported from rivers (Table 1). Most of these rivers were more than $100 \mathrm{~km}$ away from the release site, and many of them 100s of kilometres apart from each other (Fig. 2). The numbers of strays were too low to permit statistical analysis of straying rate with time of release, but the data did not suggest that the smolts released at the time of the natural smolt run, in May and June, were more successfully imprinted to the release site than those released in late summer. On the contrary, high proportions of

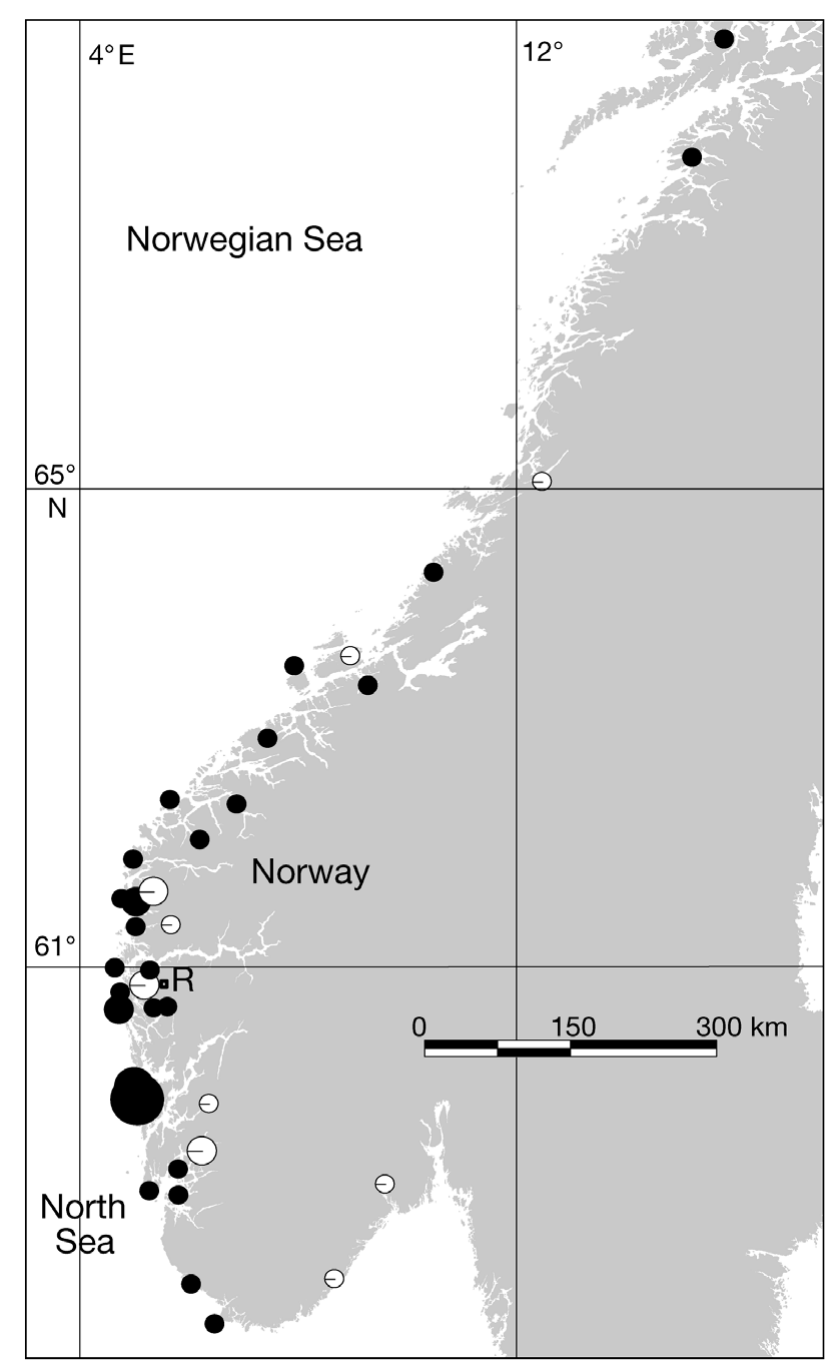

Fig. 2. Geographical distribution of recaptured Atlantic salmon Salmo salar with sea age $\geq 1+$ yr that were reported from sea (black pie charts) and rivers (white pie charts) outside the Masfjord area, Norway. A small square indicates the release site (R) and the area in the inner part of Masfjord where fish were recaptured. Sizes of the charts vary with the numbers of fish from 1 to 5

the 2 groups of fish released in July were recaptured in Masfjord (Table 1). Because of this, the interaction term between release date and the locality of recapture (in Masfjord or farther away) was close to significance when testing the influence of locality on the probability of recapture, (Eq. $2: W=10.9, \mathrm{df}=5, p_{\text {date }}$. local/distant $=0.054$; the other parameters were not significant).

Apart from the adult recaptures, the tags of 3 fish released in August 2005 were recovered in the vicinity of the release site during the following months. One was angled in late August, 1 in November, and 1 tag was found in the stomach of a pollack Pollachius pollachius in late November. 


\section{DISCUSSION}

Sea age at recapture and recapture rates of farmed smolts and post-smolts that were released from sea cages at biweekly intervals throughout their first summer in sea cages were not affected by the time of release. The weights of the recaptured fish declined slightly with the time of release. The lower recapture rate of the earliest release group deviated somewhat from the stable recapture rate of the following releases, but this did not alter the general conclusion of this study.

The reasons for the poorer survival of the first release group are unknown, but handling and transport probably caused mortality in this group just before release and may also have affected the post-release survival as demonstrated in a study by Hansen \& Jonsson (1988). Predation in the release fjord may have been higher for this group if members of the group were still influenced by the transport stress and/or did not yet display migratory behaviour, which develops over time in hatchery-reared smolts released from net pens (Skilbrei et al. 1994a,b).

The present recapture data agree well with the results obtained when post-release behaviour was studied at the same location in 2008 (Skilbrei 2010), as both outward migration speed and recapture rates remained high throughout the summer. The poorer migratory performance in September and October in the behavioural study (Skilbrei 2010) may indicate that autumn escapees are less likely to migrate to the oceanic feeding areas of wild salmon.

It is generally believed that the timing of smolt migration, and its variability with latitude, are adaptations that optimise the survival and feeding of the young salmon in the sea (Hvidsten et al. 1998). This view is supported by the higher return rates of smolts released during May and early June in earlier release experiments (Hansen \& Jonsson 1989). It was therefore surprising that, in the present study, recapture rates did not drop with progressing time of release. The recapture rates recorded by Hansen \& Jonsson (1989) were usually much higher than in the present study, but generally, the survival rates of both wild salmon and released hatchery-reared smolts in the Atlantic Ocean have declined markedly between the 1980s and recent years (Friedland et al. 2009, ICES 2010).

The timing of the migration of wild smolts varies widely and covers the whole period from April to August. In the Burrishole system in western Ireland, the majority of the smolts leave the river within a period of $4 \mathrm{wk}$ from April to June (Byrne et al. 2003). Furthermore, the time of smolt entrance into the sea is up to 6 wk later in northern than southern Norwegian rivers (Hvidsten et al. 1998), and high returns of wild smolts that migrated in early August have been observed in cold rivers in the north of Iceland (Antonsson \& Gudjonsson 2002). This variability is usually explained by environmental factors, particularly temperature, in the freshwater environment, and may be interpreted in terms of the smolt entering the sea at the first opportunity in the season, and not necessarily suggesting that there is a window for outward migration that closes at some specific time during the summer.

It remains an open question whether and to what extent the sea environment becomes less favourable for the survival of late migrating post-smolts during the summer. Oceanic variations influence salmon growth and survival (Scarnecchia 1984, Peyronnet et al. 2008), and more rapid growth of smolts in their first summer may increase both survival and the ratio of grilse to 2SW salmon (Scarnecchia et al. 1991, Friedland \& Haas 1996, Peyronnet et al. 2007). The similarity in survival and sea age among release groups observed in the present study indicates that the conditions in sea did not change significantly from June to August 2005, and the reduction in the size of the recaptured fish with time of release was very low compared to the $20 \%$ weight loss observed in a sea-ranching experiment in which the time of release ranged from May to early June (Skilbrei \& Wennevik 2006). The dominance of $1 \mathrm{SW}$ relative to multi-sea-winter salmon in recaptures recorded in the present study was not expected as the cultured strains are selected for large size at maturity and are dominated by brood fish from multi-sea-winter salmon populations (Gjedrem et al. 1991). However, age at maturity may be higher in cage-reared than in sea-ranched salmon (Saunders et al. 1983), and multisea-winter salmon experience a higher total mortality than 1SW salmon (Jonasson et al. 1994).

Improved estimates of the survival of escaped postsmolts with time of release can only be obtained by repeating the type of experiment conducted in the present study with the aim of describing inter-annual variability. Nonetheless, the present and the earlier behavioural study (Skilbrei 2010) combined show that post-smolts that escape in late summer can exhibit a migration pattern similar to that of wild salmon. This qualitative aspect of post-smolts escaped during the summer is important for the assessments of the risks of escapes. Compared with adult farmed salmon that reappear in rivers shortly after they escaped from net pens, the spawning performance and spawning success of farmed salmon that escape as young fish are believed to be much more similar to those of wild salmon (Fleming et al. 1996, 1997, Hindar et al. 2006). There is evidence of temporal genetic change in wild Atlantic salmon populations probably caused by gene flow from farmed salmon (Skaala et al. 2006), which may reduce the fitness and productivity of wild popu- 
lations (McGinnity et al. 2003). Escapes of post-smolts may therefore pose hazards to the management and protection of wild salmon populations.

Hatchery-reared smolts are expected to have a lower survival rate than wild smolts, and both hatcheryrearing and the release in a marine environment tend to increase the proportion of fish being caught in coastal compared with freshwaters (Hansen et al. 1987, Jonsson et al. 2003). In spite of this, a high percentage of the salmon released in the present study was recaptured in the vicinity of the release site. This is in accordance with the observation that the incidence of escaped farmed salmon is higher close to concentrations of fish farms in Norwegian (Fiske et al. 2006) and in North American rivers (Morris et al. 2008). It demonstrates that both smolts and post-smolts released in late summer were imprinted (Hasler \& Scholz 1983) to the release site. The salinity gradients at the release site, i.e. the variability in salinity experienced by the fish, may have been of importance for the returns. Variations in environmental conditions may influence the sensitive period for imprinting as the undiversified hatchery environment may fail to stimulate olfactory learning during earlier life stages (Lema \& Nevitt 2004). The relatively successful homing to the small Masfjord observed in the present study supports the idea of establishing marine protected areas in fjords (National Salmon Rivers and Salmon Fjords Proposition No. 79 to the Storting (2001-2002)), where aquaculture activity is prohibited or restricted, as a means of reducing the probability of escapees entering rivers that drain into these fjords.

However, the fish that did not return to the release site but entered rivers elsewhere were dispersed over a large area, similar to the dispersal of recaptures following a coastal sea-ranching experiment in the area (Skilbrei \& Holm 1998), and to the general spread of catches of homing salmon along the coast of Norway (Hansen et al. 1993). This demonstrates that escaped farmed fish present at one location may be a mixture of fish that have escaped from both adjacent and distant fish farms. Escaped farmed salmon, for example, are capable of crossing the North Sea (Hansen \& Youngson 2010). This mixture is a problem for the management of the aquaculture industry and conservation of wild resources, particularly in terms of the regulation of regional aquaculture production in order to reduce the number of escaped farmed fish in local rivers.

\section{CONCLUSIONS}

Smolts and post-smolts that escape during their first summer in sea cages present a serious challenge to the management of wild salmon populations. They are very difficult to recapture during outward migration, and the survivors will probably be geographically dispersed when they return as adults. Their spawning performance may be sufficient to present a significant risk of hybridization with wild salmon. Unless these escaped farmed fish can be removed from the rivers, improvements in the procedures and equipment used at fish farms to reduce the chance of escape seem to be the only options available to protect the wild salmon populations, apart from sterilization of farmed fish. However, little is known about the relative incidence of escapees in rivers. This topic needs to be targeted in further studies in order to improve our understanding of the significance and ecological implications of escapes at this life stage.

Acknowledgements. I am grateful to the staff at Matre Research Station for their participation during this experiment, and also thank Hugh M. Allen for his valuable comments during the writing process and the anonymous referees for their valuable comments. The Norwegian Ministry of Fisheries and Coastal Affairs and the Institute of Marine Research provided financial support.

\section{LITERATURE CITED}

Antonsson T, Gudjonsson S (2002) Variability in timing and characteristics of Atlantic salmon smolt in Icelandic rivers. Trans Am Fish Soc 131:643-655

Byrne CJ, Poole R, Rogan G, Dillane M, Whelan KF (2003) Temporal and environmental influences on the variation in Atlantic salmon smolt migration in the Burrishoole system 1970-2000. J Fish Biol 63:1552-1564

Ferguson A, Fleming I, Hindar K, Skaala O, McGinnity P, Cross TF, Prodohl P (2007) Farm escapes. In: Verspoor E, Stradmeyer L, Nielsen JL (eds) The Atlantic salmon: genetics, conservation and management. Blackwell Science, Oxford, p 310-398

Fiske P, Lund RA, Hansen LP (2005) Identifying fish farm escapees. In: Cadrin SX, Friedland KD, Waldman JD (eds) Stock identification methods. Elsevier Academic Press, Amsterdam, p 659-680

Fiske P, Lund RA, Hansen LP (2006) Relationships between the frequency of farmed Atlantic salmon, Salmo salar L., in wild salmon populations and fish farming activity in Norway, 1989-2004. ICES J Mar Sci 63:1182-1189

Fleming IA, Jonsson B, Gross MR, Lamberg A (1996) An experimental study of the reproductive behaviour and success of farmed and wild Atlantic salmon (Salmo salar). J Appl Ecol 33:893-905

> Fleming IA, Lamberg A, Jonsson B (1997) Effects of early experience on the reproductive performance of Atlantic salmon. Behav Ecol 8:470-480

Ford JS, Myers RA (2008) A global assessment of salmon aquaculture impacts on wild salmonids. PLoS Biol 6:e33

Friedland KD, Haas RE (1996) Marine post-smolt growth and age at maturity of Atlantic salmon. J Fish Biol 48:1-15

> Friedland KD, MacLean JC, Hansen LP, Peyronnet A and others (2009) The recruitment of Atlantic salmon in Europe. ICES J Mar Sci 66:289-304

Gjedrem T, Gjøen HM, Gjerde B (1991) Genetic origin of Nor- 
wegian farmed Atlantic salmon. Aquaculture 98:41-50

Hansen LP, Jonsson B (1988) Salmon ranching experiments in the River Imsa: effects of dip-netting, transport and chlorobutanol anaesthesia on survival. Aquaculture 74: 301-305

Hansen LP, Jonsson B (1989) Salmon ranching experiments in the river Imsa: effect of timing of Atlantic salmon (Salmo salar) smolt migration on survival to adults. Aquaculture 82:367-373

Hansen LP, Youngson AF (2010) Dispersal of large farmed Atlantic salmon, Salmo salar, from simulated escapes at fish farms in Norway and Scotland. Fish Manag Ecol 17: 28-32

> Hansen LP, Døving KB, Jonsson B (1987) Migration of farmed adult Atlantic salmon with and without olfactory sense, released on the Norwegian coast. J Fish Biol 30:713-721

Hansen LP, Jonsson N, Jonsson B (1993) Oceanic migration in homing Atlantic salmon. Anim Behav 45:927-941

Hasler AD, Scholz AT (1983) Olfactory imprinting and homing in salmon. Springer, New York, NY

> Hindar K, Fleming IA, McGinnity P, Diserud O (2006) Genetic and ecological effects of salmon farming on wild salmon: modeling from experimental results. ICES J Mar Sci 63: 1234-1247

Hoar WC (1976) Smolt transformation: evolution, behavior, and physiology. J Fish Res Board Can 33:1234-1252

Hvidsten NA, Heggberget TG, Jensen AJ (1998) Sea water temperatures at Atlantic salmon smolt entrance. Nord $\mathrm{J}$ Freshw Res 74:79-86

ICES (2010) Report of the working group on North Atlantic salmon (WGNAS), 22-31 March, Copenhagen. ICES CM 2010/ACOM:09. ICES, Copenhagen

Jonasson J, Johannsson V, Oskarsson S (1994) Ocean mortality of ranched Atlantic salmon during the second year in the sea. Nord J Freshw Res 69:79-83

> Jonsson B, Jonsson N (2006) Cultured Atlantic salmon in nature: a review of their ecology and interaction with wild fish. ICES J Mar Sci 63:1162-1181

> Jonsson N, Jonsson B, Hansen LP (2003) The marine survival and growth of wild and hatchery-reared Atlantic salmon. J Appl Ecol 40:900-911

LaCroix GL (2008) Influence of origin on migration and survival of Atlantic salmon (Salmo salar) in the Bay of Fundy, Canada. Can J Fish Aquat Sci 65:2063-2079

Lema SC, Nevitt GA (2004) Evidence that thyroid hormone induces olfactory cellular proliferation in salmon during a sensitive period for imprinting. J Exp Biol 207:3317-3327

Lura H, Sægrov H (1991) Documentation of successful spawning of escaped farmed female Atlantic salmon, Salmo salar, in Norwegian rivers. Aquaculture 98:151-159

McCullagh P, Nelder J 1989. Generalized linear models, 2nd edn. Chapman \& Hall, New York, NY

> McGinnity P, Prodöhl P, Ferguson A, Hynes R and others (2003) Fitness reduction and potential extinction of wild populations of Atlantic salmon, Salmo salar, as a result of interactions with escaped farm salmon. Proc R Soc Lond Ser B 270:2443-2450

Morris MRJ, Fraser DJ, Heggelin AJ, Whoriskey FG, Carr JW, O'Neill SF, Hutchings JA (2008) Prevalence and recurrence of escaped farmed Atlantic salmon (Salmo salar) in eastern North American rivers. Can J Fish Aquat Sci 65:

Editorial responsibility: Pablo Sánchez Jerez,

Alicante, Spain
$2807-2826$

Naylor R, Hindar K, Fleming IA, Goldburg R and others (2005) Fugitive salmon: assessing the risks of escaped fish from net-pen aquaculture. Bioscience 55:427-437

> Peyronnet A, Friedland KD, Maoileidigh ÓN, Manning M, Poole WR (2007) Links between patterns of marine growth and survival of Atlantic salmon Salmo salar, L. J Fish Biol 71:684-700

$>$ Peyronnet A, Friedland KD, Maoileidigh ÓN (2008) Different ocean and climate factors control the marine survival of wild and hatchery Atlantic salmon Salmo salar in the north-east Atlantic Ocean. J Fish Biol 73:945-962

Sægrov H, Urdal K (2006) Rømt oppdrettslaks i sjø og elv; mengd og opphav. (In Norwegian: 'Escaped farmed fish in the sea and in rivers; amount and origin'.) Report 947/06 21. Rådgivende Biologer AS, Bergen

Saunders RL, Henderson EB, Glebe BD, Loudenslager EJ (1983) Evidence of a major environmental component in determination of the grilse: larger salmon ratio in Atlantic salmon (Salmo salar). Aquaculture 33:107-118

Scarnecchia DL (1984) Climatic and oceanic variations affecting yield of Icelandic stocks of Atlantic salmon (Salmo salar). Can J Fish Aquat Sci 41:917-935

Scarnecchia DL, Isaksson A, White SE (1991) Effects of the Faroese long-line fishery, other oceanic fisheries and oceanic variations on age at maturity of Icelandic northcoast stocks of Atlantic salmon (Salmo salar). Fish Res 10: $207-228$

> Skaala Ø, Taggart JB, Gunnes K (2005) Genetic differences between five major domesticated strains of Atlantic salmon and wild salmon. J Fish Biol 67:118-128

> Skaala Ø, Wennevik V, Glover KA (2006) Evidence of temporal genetic change in wild Atlantic salmon, Salmo salar L., populations affected by farm escapees. ICES J Mar Sci 63: $1224-1233$

Skilbrei OT (2010) Reduced migratory performance of farmed Atlantic salmon post-smolts from a simulated escape during autumn. Aquacult Environ Interact 1:117-125

Skilbrei OT, Holm M (1998) Effects of long-term exercise on survival, homing and straying of released Atlantic salmon (Salmo salar) smolts. J Fish Biol 52:1083-1086

Skilbrei OT, Wennevik V (2006) Survival and growth of searanched Atlantic salmon, Salmo salar L., treated against sea lice prior to release. ICES J Mar Sci 63:1317-1325

Skilbrei OT, Holm M, Jørstad KE, Handeland SO (1994a) Migration motivation of cultured Atlantic salmon Salmo salar L., smolts in relation to size, time of release and acclimatization period. Aquacult Fish Manag 25:65-78

Skilbrei OT, Jørstad KE, Holm M, Farestveit E, Grimnes A, Aardal L (1994b) A new release method for coastal ranching of Atlantic salmon (Salmo salar) and behavioural patterns of released smolts. Nord J Freshw Res 69: 84-94

Smith RJF (1985) The control of fish migration. Springer-Verlag, Berlin

Thorstad EB, Økland F, Finstad B, Sivertsgård R, Bjørn PA, McKinley RS (2004) Migration speed and orientation of Atlantic salmon and sea trout post-smolts in a Norwegian fjord system. Environ Biol Fishes 71:305-311

Youngson A, Hay D (1996) The lives of salmon. Swan Hill Press, Shrewsbury

Submitted: September 13, 2010; Accepted: December 1, 2010 Proofs received from author(s): December 13, 2010 